\title{
ESRRA wt Allele
}

National Cancer Institute

\section{Source}

National Cancer Institute. ESRRA wt Allele. NCI Thesaurus. Code C101393.

Human ESRRA wild-type allele is located in the vicinity of $11 \mathrm{q} 12$ and is approximately 11

$\mathrm{kb}$ in length. This allele, which encodes steroid hormone receptor ERR1 protein, is involved in DNA binding and transcriptional activation. 